\title{
Practice of educational technologies application whitnin humanitarian disciplines training at Tyumen Industrial University
}

\section{Prática de aplicação de tecnologias educacionais whitnin treinamento em disciplinas humanitárias na Tyumen Industrial University}

\author{
Práctica de la aplicación de tecnologías educativas whitnin \\ humanitarian disciplines training en Tyumen Industrial University
}

\author{
Natalia Leonidovna Ivanova1 ${ }^{\text {iD }}$, Dmitriy Aleksandrovich Belov ${ }^{1}$ iD \\ ${ }^{1}$ Industrial University of Tyumen, Tyumen, Russia. \\ Corresponding author: \\ Natalia L. Ivanova \\ Email: Nataliaivanova701@yahoo.com
}

Ivanova, N. L., \& Belov, D. A. (2021). Practice of educational technologies application whitnin humanitarian disciplines training at Tyumen Industrial University. Revista Tempos e Espaços em Educação, 14(33), e16851.

http://dx.doi.org/10.20952/revtee.v14i33.16851

\begin{abstract}
This article examines the use of modern educational technologies in the practice of the branch of the Tyumen Industrial University in the city of Surgut. The purpose of the study is to determine a number of educational technologies used in the TIU branch in Surgut. The methodology included generalization of reference and scientific literature, questionnaires, qualitative and quantitative analysis. The study included three stages. At the first stage, reference and scientific literature was summarized to determine the concept and main directions of modern education technologies. At the second stage, the experience of using modern teaching technologies in the practice of TIU branch in the city of Surgut is presented. At the third stage, a survey of students was conducted in order to identify the effectiveness of the introduction of modern educational technologies into the practice of the Tyumen Industrial University. The study was carried out on the basis of the branch of Tyumen Industrial University in the city of Surgut, Khanty-Mansi Autonomous Okrug-Yugra. 70 respondents aged 18 to 22 took part in the study, of which 48 were males and 22 were females. The survey participants are various first, second and third year students. Before the survey, all students gave their verbal consent to the study, there were no people who refused to participate. After students assessed educational technologies at the university on a scale from 1 to 10 , the following results were obtained: $5.7 \%$. (4 people) of the respondents believe that all the conditions for the use of modern technologies already exist, $37.1 \%$ (26 people) rated it at $8-9$ points, the majority of $52.9 \%$ (37 people) of the respondents gave a rating of $6-7,4.3 \%$ ( 3 people) gave a rating of $4-5$, and none of the respondents rated the conditions for the use of modern teaching technologies at TIU as low 1-3. The number of respondents' answers in favor of each of the presented technologies was
\end{abstract}


distributed as follows: $97.1 \%$ of respondents met with the design method, $84.3 \%$ with modular rating technology, $71.4 \%$ with interactive technology, $45.7 \%$ with gaming technology, $38,6 \%$ with the technology of problem learning, $35.7 \%$ with the technology of case learning, $20.0 \%$ with the technology of developing education. The authors came to the conclusion that among the promising technologies used in the university, it should be noted interactive (58.9\%), problem-project (42.9\%), modular-rating learning technologies (37.1\%).

Keywords: Modern Educational Technologies. Modular-Rating Technology. Interactive Technology. Organizational Planning.

\section{RESUMO}

Este artigo examina o uso de tecnologias educacionais modernas na prática da filial da Universidade Industrial de Tyumen na cidade de Surgut. O objetivo do estudo é determinar uma série de tecnologias educacionais usadas na filial da TIU em Surgut. A metodologia incluiu generalização da literatura de referência e científica, questionários, análises qualitativas e quantitativas. $O$ estudo incluiu três etapas. No primeiro estágio, a literatura científica e de referência foi resumida para determinar o conceito e as direções principais das tecnologias educacionais modernas. Na segunda etapa, é apresentada a experiência da utilização de modernas tecnologias de ensino na prática da filial da TIU na cidade de Surgut. Na terceira etapa, foi realizada uma pesquisa com os alunos para identificar a eficácia da introdução de tecnologias educacionais modernas na prática da Universidade Industrial de Tyumen. $O$ estudo foi realizado com base na filial da Tyumen Industrial University na cidade de Surgut, Khanty-Mansi Autonomous Okrug-Yugra. Participaram do estudo 70 respondentes com idades entre 18 e 22 anos, sendo 48 do sexo masculino e 22 do feminino. Os participantes da pesquisa são vários alunos do primeiro, segundo e terceiro ano. Antes da pesquisa, todos os alunos deram seu consentimento verbal para o estudo, não houve pessoas que se recusaram a participar. Após os alunos avaliarem as tecnologias educacionais na universidade em uma escala de 1 a 10, foram obtidos os seguintes resultados: 5,7\%. (4 pessoas) dos respondentes acreditam que já existem todas as condições para o uso de tecnologias modernas, 37,1\% (26 pessoas) avaliou em 8-9 pontos, a maioria de 52,9\% (37 pessoas) dos respondentes deram uma avaliação de 6 a 7, 4,3\% (3 pessoas) deram uma avaliação de 4 a 5, e nenhum dos entrevistados classificou as condições para o uso de tecnologias de ensino modernas na TIU como baixas 1-3. 0 número de respostas dos entrevistados a favor de cada uma das tecnologias apresentadas foi distribuído da seguinte forma: $97,1 \%$ dos entrevistados atenderam com o método de design, $84,3 \%$ com tecnologia de avaliação modular, $71,4 \%$ com tecnologia interativa, $45,7 \%$ com tecnologia de jogos, 38, 6\% com a tecnologia de aprendizagem de problemas, 35,7\% com a tecnologia de aprendizagem de casos, $20,0 \%$ com a tecnologia de desenvolvimento de educação. Os autores concluíram que, entre as tecnologias promissoras utilizadas na universidade, destacam-se as tecnologias de aprendizagem interativa (58,9\%), projeto-problema $(42,9 \%)$ e avaliação modular (37,1\%).

Palavras-chave: Tecnologias Educacionais Modernas. Tecnologia De Classificação Modular. Tecnologia Interativa. Planejamento Organizacional.

\section{RESUMEN}

Este artículo examina el uso de tecnologías educativas modernas en la práctica de la rama de la Universidad Industrial de Tyumen en la ciudad de Surgut. El propósito del estudio es determinar una serie de tecnologías educativas utilizadas en la rama TIU en Surgut. La metodología incluyó generalización de bibliografía científica y de referencia, cuestionarios, análisis cualitativo y cuantitativo. El estudio incluyó tres etapas. En la primera etapa, se resumió la bibliografía científica y de referencia para determinar el concepto y las principales direcciones de las tecnologías educativas modernas. En la segunda etapa, se presenta la experiencia del uso de tecnologías de 
enseñanza modernas en la práctica de la sucursal TIU en la ciudad de Surgut. En la tercera etapa, se realizó una encuesta de estudiantes para identificar la efectividad de la introducción de tecnologías educativas modernas en la práctica de la Universidad Industrial de Tyumen. El estudio se llevó a cabo sobre la base de la rama de la Universidad Industrial de Tyumen en la ciudad de Surgut, KhantyMansi Autonomous Okrug-Yugra. Participaron en el estudio 70 encuestados de entre 18 y 22 años, de los cuales 48 eran hombres y 22 mujeres. Los participantes de la encuesta son varios estudiantes de primer, segundo y tercer año. Antes de la encuesta, todos los estudiantes dieron su consentimiento verbal al estudio, no hubo personas que se negaran a participar. Después de que los estudiantes evaluaran las tecnologías educativas en la universidad en una escala del 1 al 10 , se obtuvieron los siguientes resultados: $5,7 \%$. (4 personas) de los encuestados creen que ya existen todas las condiciones para el uso de tecnologías modernas, el 37,1\% (26 personas) lo calificaron con 8-9 puntos, la mayoría del 52,9\% (37 personas) de los encuestados dieron una calificación de 6-7, 4.3\% (3 personas) dieron una calificación de 4-5, y ninguno de los encuestados calificó las condiciones para el uso de tecnologías de enseñanza modernas en TIU como bajas 1-3. El número de respuestas de los encuestados a favor de cada una de las tecnologías presentadas se distribuyó de la siguiente manera: $97,1 \%$ de los encuestados cumplieron con el método de diseño, $84,3 \%$ con tecnología de clasificación modular, 71,4\% con tecnología interactiva, 45,7\% con tecnología de juegos, 38, 6\% con la tecnología de aprendizaje de problemas, 35,7\% con la tecnología de aprendizaje de casos, 20,0\% con la tecnología de desarrollo de la educación. Los autores llegaron a la conclusión de que entre las tecnologías prometedoras utilizadas en la universidad, cabe destacar las tecnologías de aprendizaje interactivo (58,9\%), problema-proyecto $(42,9 \%)$, de calificación modular $(37,1 \%)$.

Palabras clave: Tecnologías Educativas Modernas. Tecnología De Clasificación Modular. Tecnología Interactiva. Planificación Organizacional.

\section{INTRODUCTION}

Educational technology is a process system of joint activities of students and a teacher in the design (planning), organization, orientation and adjustment of the educational process in order to achieve a specific result while providing comfortable conditions for the participants (Cherevko et al., 2021; Vaganova, 2019a).

Modern pedagogical technologies are based on the theories of psychodidactics, psychology, cybernetics, control and management. They systematically and consistently put into practice a predesigned pedagogical process (Habieva et al., 2021).

The relevance of the topic of the use of modern educational technologies in the practice of the university lies in the fact that modern living conditions require from graduates more and more mobility, professionalism, communication skills, competence in various fields, the ability to simulate a situation, seek information, think critically and find a solution (Shatunova et al., 2019). In this regard, high requirements are imposed on the technologies used in the learning process at the university.

Today, a modern university teacher is required to be an organizer of independent active cognitive activity of students, a competent consultant and assistant. This role is more difficult than in traditional teaching and requires from a modern teacher not only a deep knowledge of the subject, but also high organizational skills, business skills, creativity, self-education, active participation in pedagogical competitions, master classes, forums (Konopko, et al., 2019; Vaganova, 2019b).

The purpose of this scientific article is: to determine a number of promising educational technologies used in the TIU branch in Surgut, which ensure the effective implementation of the requirements of the federal state standard of higher education.

Tasks: 
- to define the concept and main directions of modern education technologies;

- to identify what modern educational technologies are used in the practice of Tyumen Industrial University;

- to assess the effectiveness of the introduction of modern educational technologies into the practice of Tyumen Industrial University.

The object of the research is modern educational technologies of the TIU branch in Surgut.

The hypothesis of the research is that the effective use of modern educational technologies at Tyumen Industrial University makes it possible to produce competitive specialists for the oil industry of Russia.

In the process of writing the article, we studied the literature: research publications, conference materials, teaching aids for comprehension, substantiation and content of the conceptual apparatus. Among the scientists-educators engaged in the theoretical generalization of the latest pedagogical developments, one can name (Bezukladnikov et al., 2019; Gruzdeva et al., 2020; Lesia et al., 2021).

Bezukladnikov et al. (2019) and Glushchenko \& Pronkin (2020) consider modern educational technologies as "a way of cognition, carried out in the forms of joint activities of students". This is the essence of interactive methods, which consists in the fact that learning takes place in the interaction of all students and the teacher.

Associate Professor of the Faculty of Psychology and Head of the Department of Pedagogy and Psychology at Rostov State University (Abakumova, 2012) have developed didactic models of the educational process for the knowledge model of education, which is the most common in domestic universities. It finds application in traditional lectures, seminars and practical classes, where it is not yet fully possible to transfer the topic of studying a subject to an interactive study method. However, using their methodology allows students to reflect information in an unusual and broken down "on the shelves" form.

Cherevko et al. (2021) suggest distinguishing three main types of interactive methods: sociopsychological training; group discussion; game methods. Thus, it will be possible to apply several modern educational technologies within the framework of one subject of study.

In addition, Habieva et al., 2021 refer to the methods of modern teaching in order to implement educational technologies: heuristic conversation, presentations, discussions, "brainstorming", the "round table" method, the "business game" method, competitions of practical works with their discussion, role-playing games, trainings, collective solutions to creative problems, case-method, practical group and individual exercises, modeling of production processes, group work with author's manuals, discussion of special videos; pedagogical studio, meetings with invited specialists, etc.

Ilyashenko (2018) examines the use of educational technologies from the point of view of their theoretical and practical significance for assessing the functional capabilities of the body, the level of individual health; adaptation and maladjustment of students and teachers, etc. Thus, the emphasis is placed not only on how the subject will be taught, but also on how the student's body will react to the new approach. It is important that the new methodology is comfortable for both the student and the teacher (Yekimov et al., 2020).

The candidate of sciences, in turn, also sees the main task of the modernized system of modern education in the exercise of the right to receive accessible forms of education in a new, non-standard form for absolutely all categories of students, including persons with disabilities ( OVZ). It is proposed to follow the plan for the development of the information society in Russia and the objectives of the national initiative "Our New School", since it is used to implement large-scale dissemination and application of new information technologies for the development of new methods, forms and means of teaching and education (Kovalenko et al., 2021; Miloradova \& Ishkov, 2019). 
Despite the sufficient study of this topic and attempts to introduce modern educational technologies into the practice of most Russian universities, not a single highly effective educational technology in itself can guarantee success in teaching students (Vlasova et al., 2019). The main thing is the symbiosis of educational technologies and the personal qualities of the teacher. Educational technologies should be considered in conjunction with specific universities and industry areas (Lesia et al., 2021; Miloradova \& Ishkov, 2019).

Currently, there is no generally accepted concept of "pedagogical technology" in traditional pedagogy. According to the UNESCO methodology, pedagogical technologies are considered as a systematic method of creating, applying and defining the entire process of teaching and assimilating knowledge, taking into account technical and human resources and their interaction, which aims to optimize the forms of education (Darinskaia \& Molodtsova, 2019; Miloradova \& Ishkov, 2019; SUKHODIMTSEVA et al., 2018).

Analysis of the interpretation of the concept by well-known authors (Glushchenko \& Pronkin, 2020; Gruzdeva et al., 2020; Lesia et al., 2021) allows us to highlight the following characteristics, which educational technology must meet:

-conceptuality, i.e. each pedagogical technology is based on a scientific concept (Habieva et al., 2021; Kovalenko et al., 2021):

-system, i.e. it must have all the features of the system: the logic of the process, the interconnection of all parts, integrity (Glushchenko \& Pronkin, 2020);

-controllability implies the possibility of planning, designing the learning process, step-bystep diagnostics, variation in order to correct the results (Kakhkhorov \& Rasulova, 2020);

-efficiency in terms of results and optimality in terms of costs (Ilyashenko, 2018; Povzun, 2019);

- reproducibility in other institutions, by other entities (Konopko et al., 2019).

\section{METHODOLOGY}

The research was carried out in several stages. At the first stage, an analysis of the literature on the research topic was carried out. At the second stage of the study, modern educational technologies are identified, which are applied in practice at Tyumen Industrial University.

At the third stage, a closed survey was conducted among students to identify the effectiveness of the introduction of modern educational technologies into the practice of Tyumen Industrial University.

The study was carried out on the basis of the branch of Tyumen Industrial University in the city of Surgut, Khanty-Mansiysk Autonomous Okrug-Yugra. 70 respondents from 18 to 22 years old (average age $20 \pm 1.2$ ) took part in the study. Before the survey, all students gave their verbal consent to the study, there were no people who refused to participate. The template of the questionnaire card is shown in table 1 below.

Table 1. Questionnaire

\begin{tabular}{|c|c|c|}
\hline № & Question & Topic \\
\hline \multirow[t]{3}{*}{1} & $\begin{array}{l}\text { Rate the use of modern educational technologies in your university on a scale } \\
\text { from } 0 \text { to } 10 .\end{array}$ & \multirow{3}{*}{$\begin{array}{l}\text { The use of educational } \\
\text { technologies } \\
\text { (Students' } \\
\text { satisfaction) }\end{array}$} \\
\hline & Answers: & \\
\hline & a)0. b)1.c)2. d)3. e)4.f)5. g)6. h)7. z)8. y)9. t)10. & \\
\hline \multirow[t]{3}{*}{ II } & $\begin{array}{l}\text { How have the conditions for the use of modern educational technologies } \\
\text { changed over the past year? }\end{array}$ & \multirow{3}{*}{$\begin{array}{l}\text { Awareness of students } \\
\text { with the use of modern } \\
\text { educational technologies }\end{array}$} \\
\hline & Answers: & \\
\hline & $\begin{array}{l}\text { a) conditions have improved. } \\
\text { b) have not changed. } \\
\text { c) conditions worsened. }\end{array}$ & \\
\hline
\end{tabular}


III What innovative educational technologies, active forms and methods of teaching have you encountered in teaching?

\begin{tabular}{ll}
\hline Answers: & \multicolumn{2}{c}{ Familiarization of students } \\
a) instructional design method. & with the forms of \\
b) modular-rating technology. & educational technologies \\
c) credit technology. & used \\
d) gaming technology. & \\
e) case technology. & \\
f) developmental learning technologies. & \\
g) problematic technology. & \\
h) interactive technology. & \\
z) your answer. & Students' opinion \\
What learning technologies seem to you the most promising? & prospects of using modern \\
\hline Answers: & educational technologies \\
\hline a) instructional design method. & \\
b) modular-rating technology. & \\
c) credit technology. & \\
d) gaming technology. & \\
e) case technology. & \\
f) developmental learning technologies. & \\
g) problematic technology. & \\
h) interactive technology. & \\
z) your answer. &
\end{tabular}

To study the psychological level of students, we conducted a survey and testing. The research results were processed using statistical methods. The questionnaire was aimed at studying what modern educational technologies students are familiar with and which of them are most effective, based on their personal experience. The survey consisted of four blocks, each block had one question.

Thus, the study was carried out using the following methods and techniques.

1. Generalization of reference and scientific literature.

2. Questioning, ranking of results.

3. Qualitative and quantitative analysis, synthesis.

This technique is the author's, all included questions for the survey are original in nature.

To process the data obtained, we used statistical methods of analysis: descriptive statistics; nonparametric method.

\section{FINDINGS AND INTERPRETATIONS}

During the first stage, it was found that modern and traditional educational technologies differ not in what students learn, but in how they learn it. In this sense, today a large number of scientists and practicing teachers see new teaching technologies as a tool for reforming the education system (Cherevko et al., 2021; Gruzdeva et al., 2020; Ilyashenko, 2018). 
Figure 1 shows the basics of traditional and modern education technologies.

Traditional educational technologies

- on a contemplative basis

- on an empirical basis

- on a consistent basis

- on a non-anticipated basis

- on an explanatory and reproductive basis

-knowledge-based

- on an uncontested basis

- on a monologue basis

- on an academic basis
Современные образовательные технологии

-on an active basis

-conceptually

-on a large block basis

-proactively

-on a problem basis

- on a personal and semantic basis

- on an alternative basis

- on a dialogue basis

-on a case-by-case basis

Fig. 1. Basics of traditional and modern technologies education

Modern educational technologies according to their goals, content, methods used can be grouped as follows in Figure 2.

Fig. 2. Groups of modern educational technologies

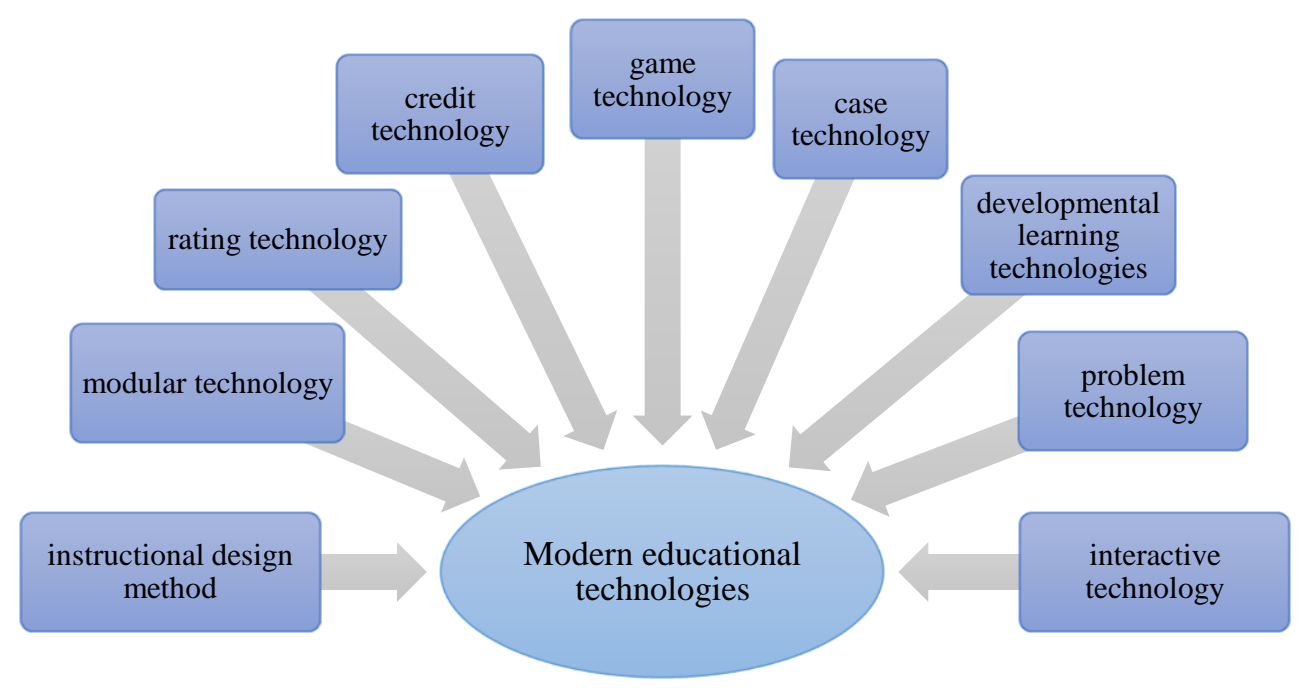

As a result of the next stage of the study, modern educational technologies used in practice at Tyumen Industrial University were identified, the following results were obtained.

Industrial University of Tyumen is one of the leading universities in the country, which was among the first to receive the status of a pivotal one. TIU is carrying out a number of systemic changes in its activities.

In close cooperation with industrial partners, promising educational programs are being developed in accordance with the needs of a changing market, the structure, content and technologies of education are being revised. This approach allows us to expand cooperation with enterprises, use their advanced infrastructure and professional potential of practitioners to train qualified personnel.

1. Educational design at TIU is an integral part of the educational process. It is actively used in disciplines starting from the 1st course "Fundamentals of project activity", on the 2nd course "Project activity" and "Theoretical mechanics and the basics of design", "Fundamentals of scientific research." The guys perform and solve complex tasks related to the future field of activity. in turn, 
they include the creation of presentations, scientific projects, writing scientific articles, creating project layouts, as well as creative projects interconnected in a team.

Instructional design technology is one of the options for organizing productive learning (Irmatov, 2020; Kovalenko et al., 2021). Students' projects can be of various types: research, creative, social, practice-oriented, innovative. Depending on the number of participants, individual projects, small-group (up to five people), group (up to 15 people), collective (llyashenko, 2018; Kakhkhorov \& Rasulova, 2020; Lesia et al., 2021).

The introduction of project-based education as a promising educational technology is important both for students and for future employers and partners of the university. In the 2019 academic year, the university held international conferences, as well as distance conferences (using the ZOOM platform) on the basis of other universities (Tomsk Polytechnic University, Ufa State Petroleum Technical University, etc.), in which students of the TIU branch presented their research projects on various topics in the oil and gas sector. In 2020, despite the distance learning period, students were also engaged in science and developed new design solutions. This was facilitated by the events held in the online format (the all-Russian platform of research projects "My country is my Russia", the competition of design works of students "Heritage of My Country", etc.).

The student receives the full scope of professional skills, skills and knowledge of the specifics of real production, at the same time develops general competencies, such as project management, organization of teamwork, communication, self-organization, responsibility, etc. hiring.

2. Modular and rating technologies work together more effectively. Modular-rating technology of the educational process, in which the content of training is presented in the form of independent, complete modules, simultaneously carry information and methodological guidance for its application, and the assessment of progress is carried out using a rating system for assessing knowledge.

In the branch of TIU in Surgut, this technology is used, for example, in the process of studying the discipline "Technological entrepreneurship". This discipline is studied by students in three stages. Each stage (module) has logical completeness and is assessed by the teacher. At the end of each module, students' knowledge is monitored in the form of a control work in a practical lesson or test. There are compulsory and additional types of work. Compulsory work includes: practical, seminar work, etc. Additional work - writing an essay, speaking at a conference, solving problems of increased complexity, participation in the Olympiad and others. For each type of activity, clear assessment criteria are defined, with which students are familiar (Gruzdeva et al., 2020; Irmatov, 2020).

The experience of students shows that as a result of the application of this system, the motivation for studying disciplines increases, since information is provided gradually and is divided into interrelated blocks, and a strong incentive is created for systematic work throughout the semester. On the downside, it can be noted that the development of modules into which the discipline for study is divided does not always include creative or additional blocks. This, in turn, does not contribute to the creative development of students.

3. Game technologies - effective organization of interaction between teacher and students. In the course of a business game, students concentrate, try to think independently, develop attention, creative thinking.

Game technologies in the TIU branch in Surgut are applied on the basis of the "Team Building" discipline. In the learning process, the qualities that a leader should have, the qualities necessary for a well-coordinated team, the problems that exist in teamwork and ways to solve them are studied. The form of play is manifested in the joint work of all students of the group - a joint task that requires teamwork: participation in the performance and its organization, development and presentation of projects. The goal is set for students in the form of a game problem, the educational material is used as a means of play; educational activity takes place with an element of competition. 
4. Case technology is an interactive technology for short-term learning based on real or imaginary situations. This technology is aimed not so much at mastering knowledge as at developing new qualities and skills in students (Darinskaia \& Molodtsova, 2019; Masalimova et al., 2017).

The case technology was used during the training practice for freshmen. In 2020, students were offered educational practice in a distance format, in the form of an online interactive case solution

"Oil case". To solve the case, the students were divided into teams of up to 4 people. The task is to develop practical skills in the field of geological exploration. With the help of this format, students gained their first experience in solving practical problems (diagnostics with logs and seismic studies, analysis of limited and conflicting information for calculating hydrocarbon reserves and geological description of the field) arising in the oil industry.

It is possible to note the use of this technology in the discipline "Project activity". 2nd year students solved the "Pipeline 2.0" case, during which it was necessary to develop and lay a main oil pipeline in a certain area. A case, as in real life, may have several solutions. The cases themselves were presented to students in various forms: printed with diagrams, tables, for clarity, video, audio, multimedia.

5. Problem-design technologies are implemented through the International Training and Training Center, the Center for Advanced Research and Development, the Higher School of Engineering EG".

The International Training Center is equipped with a full-scale computer simulator for well control DrillSim-5000, a mobile simulator DrillSim-20 and a simulator for well operation equipped with an installation of submersible electric submersible pumps (ESP) with the software package "Bringing a well equipped with an ESP to the mode and use of intelligent wells ". Classes are held in classrooms in the educational and laboratory building of Tyumen Industrial University. The total area of classrooms is $217 \mathrm{~m}^{2}$.

1. The Center for Advanced Research and Innovative Development is a territory of advanced development of research and development (R\&D) of TIU, which consists in creating a "free economic zone" that provides ease of interaction both between research teams and research teams with the services of the Center. Internal service - project management, design bureau, pilot production, coworking, certified laboratories, premises for temporary research teams (VNK) based on SMART contracts - comfortable world-class conditions for effective VNK activity. The center provides equal access for scientists and researchers to research complexes, scientific equipment and facilities,

2. The project "Higher School of Engineering EG" is aimed at creating an innovative ecosystem of education, taking into account the needs of the region and the realities of today. The introduction of new teaching methods and principles of organizing the educational space will allow the formation of engineers who are able to design tools for managing the future and be competitive in the labor market.

3. Honors Track is a project based on the EG School of Engineering. The project gives students a unique opportunity, without interrupting their basic education, to try their hand at an additional individualized project-oriented program, coordinated with the direction of training. One of the main features of Honors is the expert support of teams of students from industrial partners, because in the process of developing projects, students are faced with real problems of the oil and gas industry.

4. 6. Interactive training at TIU is organized using interactive forms - interactive lectures, seminars, master classes, trainings, etc.

5. Interactive learning at TIU is implemented through massive open online courses (MOOCs) on the TIU Open Education Platform. First-year students have the opportunity to choose between the full-time format of traditional study and courses on the MOOK platform in the 
disciplines "History", "Physics", "Mathematics". The platform also includes a complete study of the discipline, but in electronic format without the student's obligatory attendance at full-time classes, writing intermediate tests and, at the end of the study, a control test to obtain an assessment of the discipline.

6. 15 courses are now available for study on the platform. The content of the courses was developed by the authors' teams of TIU teachers. Electronic complexes include video materials, video instructions, presentation materials and were created by specialists of the Institute of Continuing and Distance Education of the flagship university. Anyone can get real professional knowledge and skills in various fields of knowledge by signing up for online courses on the TIU open education platform. Interactive learning is more in line with the principles of inclusive learning.

7. The main advantages of MOOCs are the opening up of great opportunities, the ability to independently regulate the study load and allocate time.

8. The disadvantages of such courses are high requirements for self-discipline, selforganization, the lack of the ability to control the student's reaction to the questions posed, little communication.

9. Due to these shortcomings, massive open online courses are available in individual disciplines, and not in entire programs.

10. At the final stage, a survey was conducted among students to identify the effectiveness of the introduction of modern educational technologies into the practice of Tyumen Industrial University, consisting of the following questions:

Rate the use of modern educational technologies in your university on a scale from 0 to 10.

1. How have the conditions for the use of modern educational technologies changed over the past year?

2. What innovative educational technologies, active forms and methods of teaching have you encountered in teaching? (Answer options: method of educational design / modular-rating technology / credit technology / game technologies / case technology / technologies of developing education / problem technology / interactive technology / your answer)

3. What learning technologies seem to you the most promising?

The survey results are presented in the form of diagrams. Figure 3 shows the results of the answer to the first question.

Fig. 3. Assessment of the use of modern technologies in TIU by survey respondents on a scale from 1 to 10

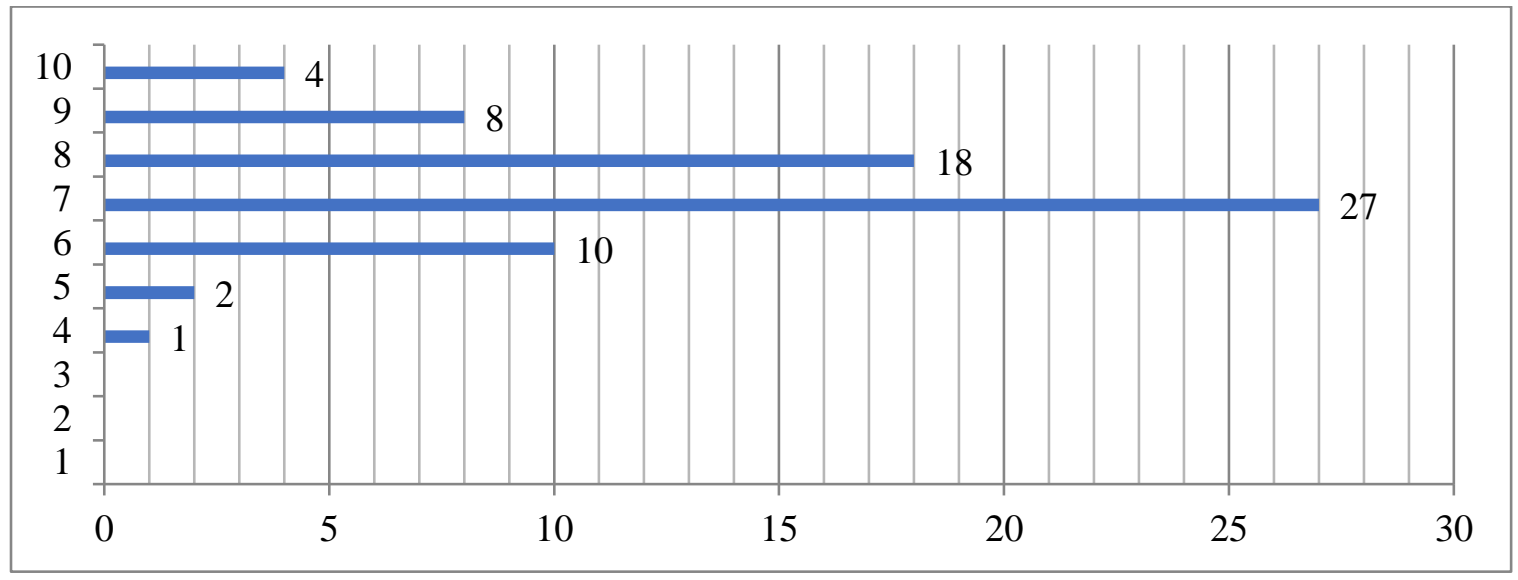

On the OU axis, the scale of answers is presented, on the OX axis, the number of respondents who gave this assessment. That is, none of the respondents assessed the conditions for the use of modern teaching technologies at TIU as low, $4.3 \%$ rated it $4-5$, the majority of $52.9 \%$ of respondents 
rated it from $6-7,37.1 \%$ rated it as $8-9$ points, and $5.7 \%$ of respondents believe that all the conditions for the use of modern technologies already exist.

To the question: "How have the conditions for the use of modern educational technologies changed over the past year?" the vast majority of respondents said that conditions have improved (75.5\%). Only $18.4 \%$ believe that they have not changed, and $7.1 \%$ have worsened. Figure 4 shows the results of the answer to the third question.

Fig. 4. Distribution of respondents' answers about the most common modern technologies in TIU

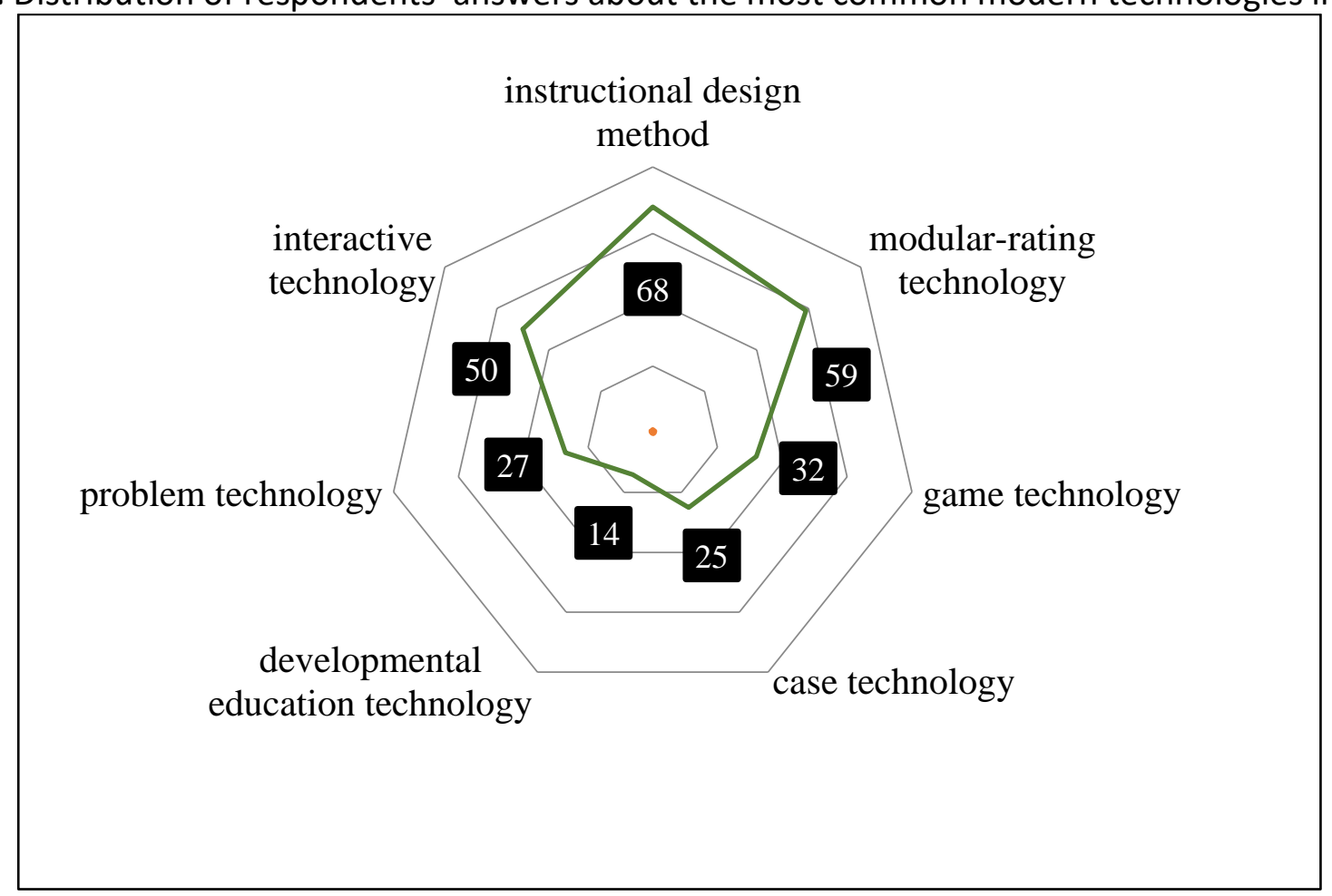

The scale of the diagram shows the number of respondents' answers in favor of each of the presented technologies that gave this rating.

$97.1 \%$ of respondents met with the design method, $84.3 \%$ with modular rating technology, $71.4 \%$ with interactive technology, $45.7 \%$ with game technology, $38.6 \%$ with problem learning technology, 35.7\% with technology case study, $20.0 \%$ with the technology of developing education. Least used credit technology; small group method; round table (forum); press conference method.

On the fourth question: "What learning technologies seem to you the most promising?" the majority of respondents chose interactive technology (58.9\%), $42.9 \%$ of respondents - problemproject learning technologies, and $37.1 \%$ - modular-rating technology.

Today, information and communication technologies can be considered a new way of transferring knowledge that corresponds to a qualitatively new content of student learning. This method allows the student to acquire new knowledge with interest, to find sources of information, fosters independence and responsibility. The use of multimedia helps to implement a studentcentered approach to learning, provides individualization and differentiation, taking into account the characteristics of students.

Thus, the data obtained as a result of the study show that TIU has created all the conditions for the use of modern teaching technologies. The university widely uses in practice design, modularrating, interactive, game technology, case technology.

However, it is not enough to create conditions for the development and application of innovative educational technologies in the educational process - it is necessary for innovative behavior to become a mass practice in the teaching environment. 
Among the promising technologies, it should be noted the interactive technology of teaching, problem-project technology of teaching, modular-rating technology.

\section{CONCLUSION}

Modern educational technology currently has such characteristics as conceptuality, consistency, controllability, efficiency, and reproducibility. Modern and traditional educational technologies differ not in what students learn, but in how they learn it.

In conclusion to the work, it is important to say that adaptation as a continuous process has a multilevel and dynamic character. The adaptive potential is genetically fixed at the individual and population level, but its implementation depends on the environment in which students acquire knowledge. But to a large extent on the format of teaching, i.e. application of modern educational technologies at the university.

One of the main forms of organizing the educational process is pedagogical control. It will allow you to check the results of educational and cognitive activities of students, pedagogical skills of the teacher and the created high-quality training system. Intensive modern teaching methods (case technology, problem technology, modular-rating technology, method of educational design and others), which have been actively introduced in recent years, can lead to new searches for effective pedagogical control and the field of improving its quality.

However, each of the above technologies is not fully applied in the branch, which is the main problem that the university faces. There are several reasons for this: 1) the emphasis is on a combination of the advantages of several learning technologies, and not specifically on one of the possible; 2 ) not every teacher uses all the proposed modules for teaching students, but only the basic or "old school" technology; 3) insufficient equipment with modern material itcommunications in classrooms, circles, assembly hall, laboratories.

Let us cite as an example the Kazan National Research Technological University (KNRTU), where game technology and problem technology are already being successfully promoted in all areas of education. Its application results in graduates with a creative mindset. In turn, the Ufa State Petroleum Technological University (USPTU) distinguished itself by the use of the method of educational design on all streams of the master's degree program in full; for the implementation of additional aspects of this technology, there is a new technological building of the university, built with the support of ROSNEFT. Thus, students are involved in project work at a new level, thanks to the availability of modern teaching technology and equipment located within the walls of the university. technology in terms of the methodology of the subject, scope and thematic direction. This will outline the main aspects of the subjects studied, the guys will get acquainted with interesting facts and theories, and will also apply a creative approach to solving the proposed tasks and posed problems. This non-standard experience will allow us to think much broader in production and technological practices and how future specialists can keep up with the times.

It should be noted that each teaching technology involves focusing on motivating students to study subjects of high quality. The given organization of the educational process, involving a productive impact on students, allows not only to successfully study the required amount of information, but by influencing the student, cause certain internal motives, their own desire to learn new things.

Authors' Contributions: Ivanova, N. L.: conception and design, acquisition of data, analysis and interpretation of data, drafting the article, critical review of important intellectual content. Belov, D. A.: conception and design, acquisition of data, analysis and interpretation of data, drafting the article, critical review of important intellectual content. All authors have read and approved the final version of the manuscript.

Ethics Approval: Not applicable. 
Acknowledgments: Not applicable.

\section{REFERENCES}

Abakumova, I. V. (2012). Fomenko VT Didakticheskii standart kak metatekhnologiia sovremennogo obrazovaniia [A didactic standard as meta-technology of modern education]. Rossiiskiipsikhologicheskiizhurnal-Russian Psychological Journal, 9(1), 44-54.

Bezukladnikov, K., Kruze, B., \& Zhigalev, B. (2019, February). Training a pre-service foreign language teacher within the linguo-informational educational environment. In The International Conference Going Global through Social Sciences and Humanities (pp. 3-14). Springer, Cham. https://doi.org/10.1007/978-3-030-11473-2_1.

Cherevko, M. A., Makuha, N. A., Vershinina, T. S., Akhmetshina, Y. V., \& Yukhnova, V. A. (2021). Using Modern Educational Technologies in a Law School (Based on Regional Experience). In SHS Web of Conferences (Vol. 108, p. 05011). EDP Sciences. https://doi.org/10.1051/shsconf/202110805011.

Darinskaia, L. A., \& Molodtsova, G. I. (Eds.). (2019). Modern technologies for teaching and learning in sociohumanitarian disciplines. IGI global.

Glushchenko, V. M., \& Pronkin, N. N. (2020). Quality of professional training as a result of innovative educational technologies. International journal of professional science, (5).

Gruzdeva, M. L., Vaganova, O. I., Kaznacheeva, S. N., Bystrova, N. V., \& Chanchina, A. V. (2020). Modern Educational Technologies in Professional Education. In Growth Poles of the Global Economy: Emergence, Changes and Future Perspectives (pp. 1097-1103). Springer, Cham. https://doi.org/10.1007/978-3-030-15160-7 110.

Habieva, T. H., Nurhodzhaeva, H. A., Tretyakova, S. N., Zharmedetov, T. M., Zhunusova, S., Syzdykova, A., \& Auganbaeva, T. (2021). THE USE OF MODERN EDUCATIONAL TECHNOLOGIES IN IMPROVING THE COMPETENCIES AND COMPETITIVENESS OF UNDERGRADUATES. Global Science and Innovations: Central Asia (см. в книгах), 2(12), 110114. https://www.elibrary.ru/item.asp?id=46395944.

Ilyashenko, L. K. (2018). Application of project activities in the theory and practice of Russian universities. Revista ESPACIOS, 39(25).

Irmatov, F. M. (2020). FEATURES TEACHING PHYSICS FOR STUDENTS DIRECTIONS IN NON-PHYSICAL SPECIALTY BASED ON MODERN EDUCATIONAL TECHNOLOGIES. Scientific Bulletin of Namangan State University, 2(7), 263-268. Available at: https://uzjournals.edu.uz/namdu/vol2/iss7/47.

Kakhkhorov, S. K., \& Rasulova, Z. D. (2020). Methodology of improving the professional activity of the future teacher of technology on the basis of modern educational technologies. Universal J. of Educational Research, 8(12), 70067014. https://doi.org/10.13189/ujer.2020.081268.

Konopko, E., Pankratova, O., Nersesyan, E., \& Abdullaev, J. (2019, May). Training of teachers for professional activity in the digital environment of the educational space. In Proceedings of SLET-2019-International Scientific Conference Innovative Approaches to the Application of Digital Technologies in Education and Research, Stavropol-Dombay, Russia (pp. 205-212).

Kovalenko, O. V., Yepyk, L. I., Yeromenko, A. Y., Kashynska, O. Y., \& Bezruchenkov, Y. V. (2021). Training of the future tourist guides for intercultural communicative interaction within professional activity. Linguistics and Culture Review, 5(S4), 729-746. https://doi.org/10.21744/lingcure.v5nS4.1712

Lesia, S., Yulia, V., Kateryna, M., Lyudmyla, R., Yakimets, S., \& Maksym, K. (2021, September). Use of Modern Educational Technologies in the Electrical Engineers and Electromechanics Preparation by a Blended Learning System. In 2021 IEEE International Conference on Modern Electrical and Energy Systems (MEES) (pp. 1-5). IEEE.

https://doi.org/10.1109/MEES52427.2021.9598702.

Masalimova, A. R., Levina, E. Y., Platonova, R. I., Yakubenko, K. Y., Mamitova, N. V., Arzumanova, L. L., ... \& Marchuk, N. N. (2017). Cognitive simulation as integrated innovative technology in teaching of social and humanitarian 
disciplines. EURASIA Journal of Mathematics, Science and Technology Education, 13(8), 4915-4928.

https://doi.org/10.12973/eurasia.2017.00973a.

Miloradova, N. G., \& Ishkov, A. D. (2019). Training of the highly qualified personnel in the postgraduate study in Russia and Tajikistan: results of the sociological poll. Abstracting/Indexing, 336.

Povzun, V. (2019). The role of the modern educational technologies in the development of system thinking of university students. Contemporary Higher Education: Innovative Aspects/Sovremennaia Vysshaia Shkola: Innovatsionny Aspect, 11(4), 45-51. https://doi.org/10.7442/2071-9620-2019-11-4-45-51.

Shatunova, O., Anisimova, T., Sabirova, F., \& Kalimullina, O. (2019). Steam as an innovative educational technology. Journal of Social Studies Education Research, 10(2), 131-144. https://www.learntechlib.org/p/216582/.

SUKHODIMTSEVA, A. P., SERGEEVA, M. G., DONSKAYA, M. V., KUPRIYANOVA, M. E., \& TOMASHEVICH, S. B. (2018). Metadisciplinarity in education: Solving actual problems. Revista ESPACIOS, 39(02).

https://www.revistaespacios.com/a18v39n02/18390227.html.

Vaganova, O. I. (2019a). Organization of practical classes in a higher ed ucational institution using modern educational technologies. Amazonia Investiga, 8(23), 81-86. Retrieved from https://www.amazoniainvestiga.info/index.php/amazonia/article/view/850.

Vaganova, O. I. (2019b). Formation of competence in the possession of modern educational technologies at a university. Amazonia Investiga, 8(23), 87-95. Retrieved from

https://amazoniainvestiga.info/index.php/amazonia/article/view/851.

Vlasova, E. Z., Avksentieva, E. Y., Goncharova, S. V., \& Aksyutin, P. A. (2019). Artificial intelligence-The space for the new possibilities to train teachers. Espacios, 40(9), 17.

Yekimov, S., Getmanets, G., Miroshnik, L., Sosnina, T., Havrylenko, A., Vasylieva, N., ... \& Bondarenko, Z. (2020, November). Some problems of humanitarian training of future specialists in pedagogical specialties using interactive technologies. In Journal of Physics: Conference Series (Vol. 1691, No. 1, p. 012221). IOP Publishing. https://doi.org/10.1088/1742-6596/1691/1/012221.

Received: 31 July 2021 | Accepted: 7 November 2021 | Published: 07 December 2021 